\title{
Anilinolysis of $S$-Aryl Phenyl Phosphonochloridothioates in Acetonitrile
}

\author{
Bilkis Jahan Lumbiny and Hai Whang Lee* \\ Department of Chemistry, Inha University, Incheon 402-751, Korea. "E-mail: hwlee(alma.ackr \\ Received September 8. 2008
}

Key Words : Anilinolysis, S-Aryl phenyl phosphonochloridothioates, Deuteriun kinetic isotope effect, Frontside nucleophilic attack, Steric effect

In our preceding papers, ${ }^{1}$ we reported various phosphoryl and thiophosphoryl transfer reactions. Continuing our studies on thiophosphoryl transfer reactions, we have carried out kinetic studies of the reactions of Y-S-aryl phenyl phosphonochloridothioates (1) with $\mathrm{X}$-anilines in acetonitrile at $55.0^{\circ} \mathrm{C}$ to clarify the anilinolysis mechanism and stereochemistry by comparing the reactivity, the sign of the crossinteraction constants, ${ }^{2}$ the steric effects, and finally the deuterium kinetic isotope effects (KIEs) with those obtained in the previous work.

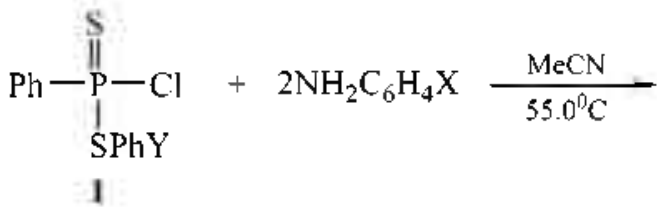

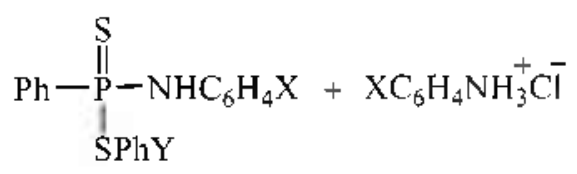

$$
\begin{aligned}
& \mathrm{X}=4-\mathrm{MeO}, 3-\mathrm{Me}, \mathrm{H}, 4-\mathrm{Cl}, 3-\mathrm{Cl} \\
& \mathrm{Y}=4-\mathrm{MeO}, 4-\mathrm{Me}, 3-\mathrm{Me}, \mathrm{H}, 3-\mathrm{MeO}
\end{aligned}
$$

The pseudo-first-order rate constants observed $\left(k_{0 \mathrm{bss}}\right)$ for all reactions obeyed eq. (2) with negligible $k_{0}(\approx 0)$ in acetonitrile. The clean second-order rate constants, $k_{\mathrm{H}(\mathrm{D})}$, were obtained as the slope of the plot of $k_{\text {wbst }}$ against aniline concentration.

$$
k_{\mathrm{obsd}}=k_{0}+k_{\mathrm{H}}[\mathrm{X}-\mathrm{An}]
$$

The second-order rate constants $\left(k_{\mathrm{H}}\right)$ for the reactions of $\mathbf{1}$ with $\mathrm{X}$-anilines in acetonitrile at $55.0^{\circ} \mathrm{C}$ are summarized in
Table 1 together with selectivity parameters, $\rho_{\mathrm{X}}, \beta_{\mathrm{X}}, \rho_{\mathrm{Y}}$, and $\rho_{X Y}$. The rate increases with a more electron-withdrawing substituent $Y$ in the substrate and with a more electrondonating substituent $\mathrm{X}$ in the nucleophile which is consistent with a typical nucleophilic substitution reaction with negative charge development at the reaction center $\mathrm{P}$ in the transition state (TS).

Figure 1 shows the plot of $\rho_{\mathrm{X}} v^{\prime} \sigma_{\mathrm{Y}}$ and $\rho_{\mathrm{Y}} v^{\prime} \sigma_{\mathrm{X}}$ (eqs. 3) for the anilinolysis of 1 with good linearities. The negative $\rho_{X Y}(=-0.31)$ value implies the rate-limiting nucleophilic bond formation." A more electron-withdrawing substituent $\left(\partial \sigma_{\mathrm{Y}}>0\right)$ in the substrate leads to a greater degree of bond formation ( $\partial \rho_{\mathrm{X}}<0$ or $\left|\partial \rho_{\mathrm{X}}\right|>0$ ), resulting in $\rho_{\mathrm{XY}}=\partial \rho_{\mathrm{X}} / \partial \sigma_{\mathrm{Y}}$ $<0$. A stronger nucleophile $\left(\partial \sigma_{\mathrm{X}}<0\right)$ leads to greater negative charge development at the reaction center $\left(c \rho_{Y}>0\right)$ because of greater bond formation, resulting in $\rho_{\mathrm{XY}}=\partial \rho_{\mathrm{Y}} /$ $\partial \sigma_{\mathrm{X}}<0$. The negative sign of $\rho_{\mathrm{XY}}$ is in agreement with the concerted mechanism, ${ }^{2}$ as observed in the anilinolysis of aryl phenyl chlorothiophosphates $\left(\rho_{\mathrm{XY}}=-0.22\right)^{1 \mathrm{c}}$ and aryl ethyl chlorothiophosphates $\left(\rho_{\mathrm{KY}}=-0.28\right) .{ }^{1 \mathrm{f}}$

$$
\begin{gathered}
\log \left(k_{\mathrm{XY}} / k_{\mathrm{HH}}\right)=\rho_{\mathrm{X}} \sigma_{\mathrm{X}}+\rho_{\mathrm{Y}} \sigma_{\mathrm{Y}}+\rho_{\mathrm{XY}} \sigma_{\mathrm{X}} \sigma_{\mathrm{Y}} \\
\rho_{\mathrm{XY}}=\partial \rho_{\mathrm{X}} / \partial \sigma_{\mathrm{Y}}=\partial \rho_{\mathrm{Y}} / \partial \sigma_{\mathrm{X}}
\end{gathered}
$$

The KIEs with deuterated anilines in the present work are summarized in Table 2 . The obtained primary normal KIEs $\left(k_{\mathrm{H}} / k_{\mathrm{D}}=1.15-1.59>1\right)$ indicate that partial deprotonation of the aniline nucleophile occurs in the rate-limiting step by hydrogen bonding. A concerted mechanism involving a partial frontside nucleophilic attack through a hydrogenbonded, four-center-type TS I accompanied by a backside

\begin{tabular}{|c|c|c|c|c|c|c|}
\hline $\mathrm{X} \backslash \mathrm{Y}$ & $4-\mathrm{MeO}$ & $4-\mathrm{Me}$ & $3-\mathrm{Me}$ & $\mathrm{H}$ & 3-MeO & $\rho_{l}^{\prime}$ \\
\hline 4- $\mathrm{MeO}$ & $107=3$ & $119=3$ & $128=1$ & $144 \pm 3$ & $168 \pm 1$ & $0.50=0.01$ \\
\hline 3-Me & $16.1=0.1$ & $18.0 \pm 0.1$ & $19.9=0.2$ & $21.9 \pm 0.1$ & $24.0=0.5$ & $0.45=0.01$ \\
\hline $\mathrm{H}$ & $12.6=0.2$ & $14.6 \pm 0.3$ & $16.7=0.1$ & $17.5 \pm 0.4$ & $18.4=0.1$ & $0.43=0.02$ \\
\hline 4-Cl & $2.66=0.05$ & $2.75 \pm 0.03$ & $2.88=0.07$ & $3.17 \pm 0.01$ & $3.72=0.05$ & $0.37=0.02$ \\
\hline $3-\mathrm{Cl}$ & $0.613=0.002$ & $0.665 \pm 0.005$ & $0.697=0.004$ & $0.742=0.010$ & $0.798=0.017$ & $0.29=0.01$ \\
\hline$-\rho x^{b}$ & $3.35=0.10$ & $3.39 \pm 0.09$ & $3.42=0.09$ & $3.45 \pm 0.09$ & $3.47=0.10$ & $a$ \\
\hline$\beta$ & $1.21=0.05$ & $1.22 \pm 0.04$ & $1.23=0.04$ & $1.24 \pm 0.04$ & $1.25=0.05$ & 08 \\
\hline
\end{tabular}
nucleophilic attack with a trigonal bipyramidal pentacoordinate (TBP-5C) TS II is proposed in the present work, tor

Table 1. Second-Order Rate Constants $\left(k_{\mathrm{H}} \times 10^{5} \mathrm{M}^{-1} \mathrm{~s}^{-1}\right)$ and Selectivity Parameterst of the Aminolysis of Y-S-aryl Phenyl Phosphonochloridothioates (1) with $\mathrm{X}$-Anilines in Acetonitrile at $55.0^{\circ} \mathrm{C}$

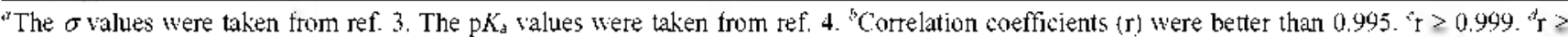
$0.955 .{ }^{\prime \prime} \mathrm{r}=0.991$ 


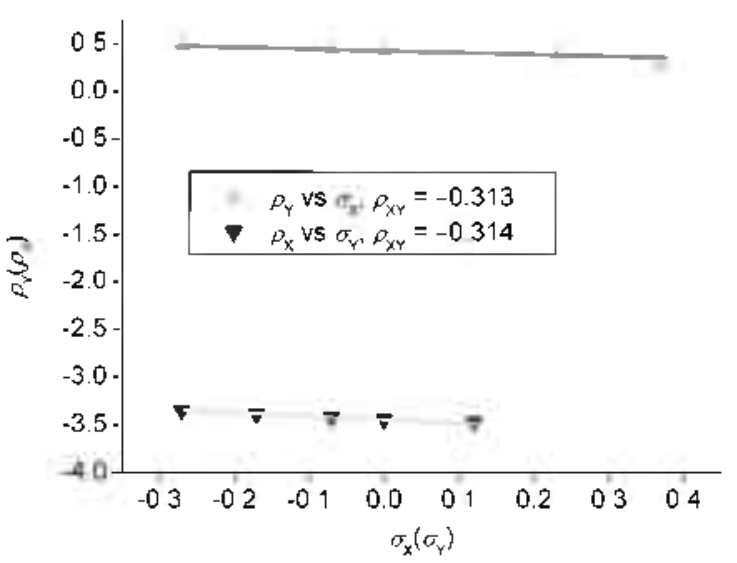

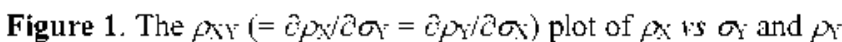
is $\alpha$ of the reactions of Y-S-aryl phenyl phosphonochloridothioates (1) with $\mathrm{X}$-anilines in acetonitrile at $55.0^{\circ} \mathrm{C}$.

Table 2. Second-Order Rate Constants $\left(k_{\mathrm{H}_{1} \mathrm{OH}} \times 10^{5} / \mathrm{M}^{-1} \mathrm{~s}^{-1}\right)$ and Kinetic Isotope Effects $\left(k_{\mathrm{H}} / k_{\mathrm{D}}\right)$ for the Aminolysis of Y-S-Aryl Phenyl Phosphonochloridothioates with $\mathrm{XC}_{6} \mathrm{H}_{4} \mathrm{NH}_{2}$ and $\mathrm{XC}_{6} \mathrm{H}_{4} \mathrm{ND}_{2}$ in Acetonitrile at $55.0^{\circ} \mathrm{C}$

\begin{tabular}{ccccc}
\hline $\mathrm{X}$ & $\mathrm{Y}$ & $k / \times 10^{5} / \mathrm{M}^{-1} \mathrm{~s}^{-1}$ & $k \times 10^{5} / \mathrm{M}^{-1}$ & $k_{1} / k_{0}$ \\
\hline $4-\mathrm{MeO}$ & $4-\mathrm{Me}$ & $119 \pm 3$ & $77.8 \pm 0.6$ & $1.53 \pm 0.04^{*}$ \\
$4-\mathrm{MeO}$ & $\mathrm{H}$ & $144=3$ & $90.4 \pm 0.4$ & $1.59 \pm 0.03$ \\
$4-\mathrm{MeO}$ & $3-\mathrm{MeO}$ & $168=1$ & $108 \pm 1$ & $1.56 \pm 0.02$ \\
$\mathrm{H}$ & $4-\mathrm{Me}$ & $14.6=0.3$ & $10.2 \pm 0.1$ & $1.43 \pm 0.03$ \\
$\mathrm{H}$ & $\mathrm{H}$ & $17.5=0.4$ & $12.0 \pm 0.1$ & $1.46 \pm 0.04$ \\
$\mathrm{H}$ & $3-\mathrm{MeO}$ & $18.4=0.1$ & $13.3 \pm 0.3$ & $1.38 \pm 0.03$ \\
$3-\mathrm{Cl}$ & $4-\mathrm{Me}$ & $0.665=0.005$ & $0.534 \pm 0.009$ & $1.25 \pm 0.02$ \\
$3-\mathrm{Cl}$ & $\mathrm{H}$ & $0.742=0.010$ & $0.597 \pm 0.004$ & $1.24 \pm 0.02$ \\
$3-\mathrm{Cl}$ & $3-\mathrm{MeO}$ & $0.798=0.017$ & $0.695 \pm 0.018$ & $1.15 \pm 0.04$ \\
\hline
\end{tabular}

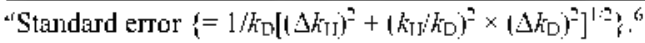

the same reasons as in the anilinolysis of aryl phenyl chlorothiophosphates [2: (YPhO)(PhO)P(S)Cl], ${ }^{\text {le }}$ diphenyl thiophosphinic chloride [3: $\left.\mathrm{Ph}_{2} \mathrm{P}(\mathrm{S}) \mathrm{Cl}\right]$, ${ }^{\text {le }}$ aryl ethyl chlorothiophosphates [4: (YPhO)(EtO)P(S)Cl], ${ }^{\text {it }}$ diethyl chlorothiophosphate [5: $\left(\mathrm{EtO}_{2} \mathrm{P}(\mathrm{S}) \mathrm{Cl}\right]{ }^{\text {ly }}$ and dimethyl chlorothiophosphate [6: $\left.(\mathrm{MeO})_{2} \mathrm{P}(\mathrm{S}) \mathrm{Cl}\right]$. $^{\text {lo }}$<smiles>[R3][Sb](C)(=S)(Cl)N([In])I</smiles>

TS I

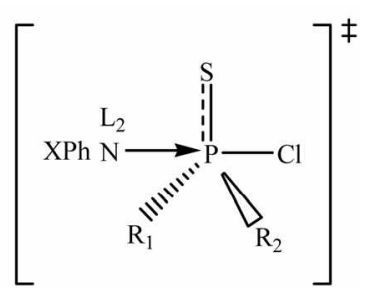

TS II

$$
\mathrm{L}=\mathrm{H} \text { or } \mathrm{D}
$$

The observed primary normal KIEs may be proportional to the degree of hydrogen bond formation. Greater deprotonation would occur with greater bond formation, that is, the stronger nucleophile $\left(\partial \sigma_{\mathrm{X}}<0\right)$ leads to a greater hydrogen bond formation $\left(\partial \rho_{\mathrm{Y}}>0\right)$, resulting in $\rho_{\mathrm{XY}}=\partial \rho_{\mathrm{Y}} / \partial \sigma_{\mathrm{X}}<0$. This deduction is consistent with the obtained sequence of $k_{\mathrm{H}} / k_{\mathrm{D}}$ values as shown in Table 2 . The observed $k_{\mathrm{H}} / k_{\mathrm{D}}$ values

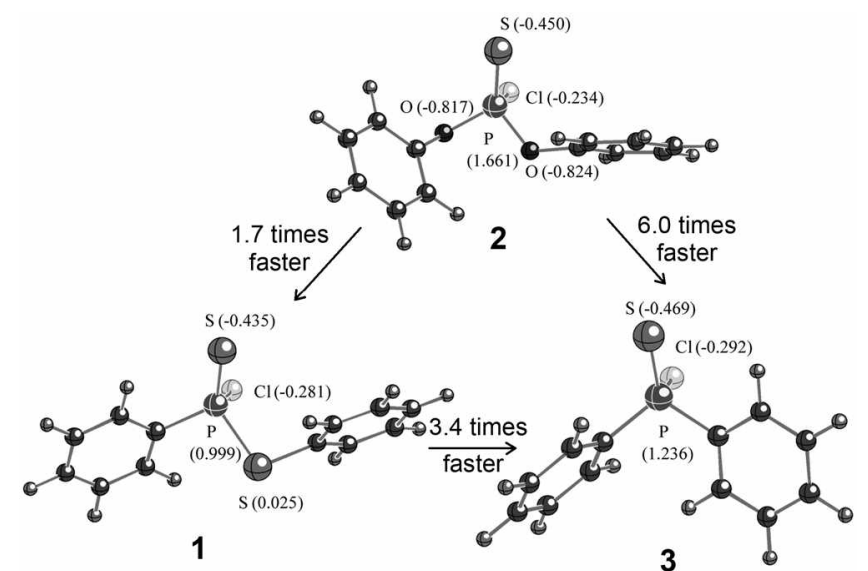

Figure 2. The B3LYP:6-311+G(d.p $)^{7}$ geometries and NBO charges of S-phenyl phenyl phosphonochloridothioate [1 with $\mathrm{Y}=\mathrm{H}$ : $(\mathrm{PhS}) \mathrm{PhP}(\mathrm{S}) \mathrm{Cl}]$, diphenyl chlorothiophosphate $[2$ with $\mathrm{Y}=\mathrm{H}$ : $\left.(\mathrm{PhO})_{2} \mathrm{P}(\mathrm{S}) \mathrm{C} 1\right]^{\text {li }}$ and diphenyl thiophosphinic chloride [3: $\left.\mathrm{Ph}_{2} \mathrm{P}(\mathrm{S}) \mathrm{Cl}\right]^{\text {sd }}$ in the gas phase. The anilinolysis $\left(\mathrm{C}_{6} \mathrm{H}_{3} \mathrm{NH}_{2}\right)$ rate ratios in acetonitrile at $55.0^{\circ} \mathrm{C}$ are displayed next to the arrows.

in Table 2 would be the sum of (i) the primary normal KIE, $k_{\mathrm{H}} / k_{\mathrm{D}}>1$, because of the partial deprotonation of one of the two N-H(D) bonds in the TS I for a frontside attack, (ii) the secondary inverse $\mathrm{KIE}, k_{\mathrm{H}} / k_{\mathrm{D}}<1$, because of the steric hindrance that increases the out-of-plane bending vibrational frequencies of the other $\mathrm{N}-\mathrm{H}(\mathrm{D})$ bond in TS I for a frontside attack, (iii) the secondary inverse $\mathrm{KIE}, k_{\mathrm{H}} / k_{\mathrm{D}}<1$, because of the steric congestion that increases the vibrational frequencies of both of the $\mathrm{N}-\mathrm{H}(\mathrm{D})$ bonds in TS II for a back-side attack. ${ }^{5}$ Thus, the real primary KIE due to the hydrogen bond between the hydrogen of the N-H(D) moiety and the $\mathrm{Cl}$ leaving group should be greater than the observed value.

As shown in Figure 2, the natural bond order (NBO) charges, using the B3LYP/6-311+G(d,p) level, ${ }^{7}$ on the reaction center $\mathrm{P}$ are 0.999 (for 1 ), 1.661 (for 2), ${ }^{\mathrm{l}}$ and 1.236 (for 3) . Solely considering the NBO charge on the reaction center, the reactivities of the substrates should increase in the following order: $\mathbf{1}<\mathbf{3}<\mathbf{2}$. However, the sequence of the second-order rate constants, $\mathbf{2}<\mathbf{1}<\mathbf{3}$, is not consistent with the expectations for the NBO charge on the reaction center $\mathrm{P}$. The anilinolysis rate of $\mathbf{1}$ is 1.7 times faster than that of $\mathbf{2}$ The rate of $\mathbf{3}$ is 6.0 times faster than that of $\mathbf{2}$ and the rate of 3 is 3.4 times faster than that of $\mathbf{1}$. The rate increases upon replacing a larger ligand ( $\mathrm{PhO}$ or $\mathrm{PhS}$ ) into a smaller ligand (Ph), suggesting that the steric effects play an important role to determine the reactivities of $\mathrm{P}=\mathrm{S}$ systems.

The second-order rate constants, relative rate ratios, $\mathrm{NBO}$ charges on $\mathrm{P}$ reaction centers, KIEs $\left(k_{\mathrm{H}} / k_{\mathrm{D}}\right)$, Brönsted $\beta_{\mathrm{X}}$ values, and cross-interaction constant $\rho_{\mathrm{XY}}$ values for the anilinolysis of 1-6 in acetonitrile at $55.0^{\circ} \mathrm{C}$ are summarized in Table 3. Relatively large Brönsted $\beta_{x}\left(\beta_{3 u c}=0.9-1.4\right)$ values of the anilinolysis of the studied reaction systems (16) suggest extensive bond formation in the TS. These values are considerably larger than those of other nucleophilic substitution reactions of $\mathrm{P}=\mathrm{O}$ and $\mathrm{P}=\mathrm{S}$ systems in which the reactions proceed by a concerted mechanism. The large $\beta_{\mathrm{X}}$ 
Table 3. Summary of the Second-Order Rate Constants, Relative Rate Ratios, NBO Charges on P Reaction Centers, Kinetic Isotope Effects $\left(k_{\mathrm{H}} / k_{\mathrm{D}}\right)$. Brönsted $\beta_{\mathrm{R}}$ Values, and Cross-Interaction Constant $\beta \mathrm{N}$ values for the Anilinolysis of $\mathrm{R}_{\mathrm{l}} \mathrm{R}_{-} \mathrm{P}(\mathrm{S}) \mathrm{Cl}$ in $\mathrm{Acetonitrile}$ at $55.0^{\circ} \mathrm{C}$

\begin{tabular}{|c|c|c|c|c|c|c|c|c|c|}
\hline No & $\mathrm{R}_{1}$ & $\mathrm{R}:$ & $k_{\mathrm{T}} \times 10^{4} / \mathrm{M}^{-1} \mathrm{~s}^{-\mathrm{l} c}$ & $k_{\mathrm{Tic}}{ }^{h}$ & NBO charge on $\mathrm{P}$ & $k_{17} / k_{\mathrm{D}}$ & $\beta_{\mathrm{x}}$ & $-\rho \mathrm{NT}$ & ref. \\
\hline 6 & $\mathrm{MeO}$ & $\mathrm{MeO}$ & 10.9 & 11 & 1.687 & $0.95-1.06$ & 0.993 & - & $\lg$ \\
\hline 3 & $\mathrm{Pl}$ & $\mathrm{Pl}$ & 6.01 & 6.0 & 1.236 & $1.00-1.10$ & 1.40 & - & le \\
\hline 5 & Eto & EtO & 5.12 & 5.0 & 1.701 & $1.01-1.10$ & 0.977 & - & $\lg$ \\
\hline 4 & YPhO & EtO & 2.80 & 2.8 & 1.687 & $1.06-1.27$ & $1.10-1.19$ & 0.28 & $1 \mathrm{f}$ \\
\hline 1 & YPhS & $\mathrm{Ph}$ & 1.75 & 1.7 & 0.999 & $1.15-1.59$ & $1.21-1.25$ & 0.31 & This work \\
\hline 2 & YPhO & $\mathrm{PhO}$ & 1.01 & 1 & 1.661 & $1.11-1.33$ & $1.34-1.41$ & 0.22 & lc \\
\hline
\end{tabular}

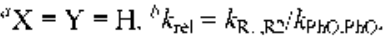

values seem to be characteristic of the anilinolysis of $\mathrm{P}=\mathrm{O}$ and $\mathrm{P}=\mathrm{S}$ systems with the $\mathrm{Cl}$ leaving group. ${ }^{\text {lat }}$ When we compare the reactivities of the thiophosphates $\left[\left(\mathrm{R}_{1}{ }^{1} \mathrm{O}\right)\right.$ $\left.\left(\mathrm{R}_{2} \mathrm{O}\right) \mathrm{P}(\mathrm{S}) \mathrm{Cl}\right]$, the $\mathrm{NBO}$ charges of $\mathrm{P}$ reaction centers do not explain the obtained rate ratios explicitly. The rates increase as the sizes of the ligands are getting smaller: 2 (with two $\mathrm{PhO}$ ) $<4$ (with single $\mathrm{PhO}$ and $\mathrm{EtO}$ ) $<5$ (with two EtO) $<6$ (with two $\mathrm{MeO}$ ), i.e., the relative rate ratios of $2,4,5$, and 6 are $1: 2.8: 5.0: 11$. Therefore, it is clear that the steric effect is a major factor to determine the reactivities of $\mathrm{P}=\mathrm{S}$ systems, as well as $\mathrm{P}=\mathrm{O}$ systems. lif:

In the anilinolysis of $6{ }^{1}{ }^{1}$ the $k_{\mathrm{H}} / k_{\mathrm{D}}$ values of the weaker nucleophiles ( $\mathrm{X}=3-\mathrm{Cl}, 4-\mathrm{Cl}, 3-\mathrm{MeO}$, and $\mathrm{H}$ ) are less than unity, while those of the stronger nucleophiles $(\mathrm{X}=4-\mathrm{MeO}$, 4-Me, and 3-Me) are larger than unity. In an $\mathrm{S}_{\mathrm{N}} 2$ mechanism. the secondary inverse $\mathrm{KIE}\left(k_{\mathrm{H}} / k_{\mathrm{D}}<1\right)$ is ascribed to the increment of the vibrational frequencies of N-H(D) in the TS II due to an increase in steric crowding in the bond-making process. ${ }^{8}$ This implies that a backside nucleophilic attack is dominant for the weaker nucleophiles, while a frontside nucleophilic attack is dominant for the stronger nucleophiles. The backside nucleophilic attack for the weaker nucleophiles is possible because of the relatively small sizes of two $\mathrm{MeO}$ ligands. ${ }^{1 \mathrm{k}}$

The small $\Delta H^{F}$ values and large negative $\Delta S^{\mp}$ values are characteristic of relatively late TS with a large degree of bond formation and breaking. ${ }^{9}$ Since the $\mathrm{Cl}$ leaving group is a strong nucleofige, a large degree of bond breaking will not require a lot of energy and a large degree of bond formation will provide partial bond energy in the TS, resulting in small positive $\Delta H^{*}$ values. The large negative $\Delta S^{*}$ values may result from a large degree of bond breaking and also steric hindrance in the bond formation of aniline.

\section{Summary}

The reactions of S-aryl phenyl phosphonochloridothioates with anilines and deuterated anilines are investigated kinetically in acetonitrile at $55.0^{\circ} \mathrm{C}$. A negative cross-interaction constant $\left(\rho_{\mathrm{XY}}=-0.31\right)$ and primary normal kinetic isotope effects $\left(k_{\mathrm{H}} / k_{\mathrm{D}}=1.15-1.59\right)$ are consistent with a concerted process with a partial frontside nucleophilic attack through a hydrogen-bonded, four-center-type TS accompanied by a backside nucleophilic attack with a trigonal bipyramidal pentacoordinate TS.

\section{Experimental Section}

Materials. GR grade phenyl thiophosphonic dichloride, anilines, thiophenols, triethylamine, and deuterium oxide $\left(\mathrm{D}_{2} \mathrm{O} ; 99.9\right.$ atom $\%$ D) were used without further purification except anilines. Anilines were generally recrystallized or distilled for further purification before use. HPLC-grade $\mathrm{MeCN}$ (water content is less than $0.005 \%$ ) were used without further purification for kinetics study. Deuterated anilines were prepared by heating anilines with $\mathrm{D}_{2} \mathrm{O}$ at $85^{\circ} \mathrm{C}$ for $72 \mathrm{~h}$ and confirmed by ${ }^{l} \mathrm{H}-\mathrm{N} \mathrm{MR}$. Y-S-aryl phenyl phosphonochloridothioates were prepared by the following single step reaction. The equimolar starting materials, pheny! thiophosphonic dichloride, thiophenols, and triethyl amine were mixed and stirred in methylene chloride solvent, keeping in an ice bath for 18-20 hrs. The physical constants of substrates after isolation by column chromatography are as follows

$S$-(4-Methoxyphenyl) phenyl phosphonochloridothioate. White solid; mp $68-70{ }^{\circ} \mathrm{C} ;{ }^{1} \mathrm{H}$ XMR $\left(400 \mathrm{MHz}, \mathrm{CDCl}_{3}\right)$ $\delta 7.97(\mathrm{dd}, J=16.6,6.4 \mathrm{~Hz}, 2 \mathrm{H}), 7.59-7.55(\mathrm{~m}, 1 \mathrm{H}), 7.50-$ $7.45(\mathrm{~m}, 2 \mathrm{H}), 7.33-7.29(\mathrm{~m}, 2 \mathrm{H}), 6.84(\mathrm{~d}, J=7.6 \mathrm{~Hz}, 2 \mathrm{H})$, $3.80\left(\mathrm{~s}, 3 \mathrm{H}, \mathrm{OCH}_{3}\right) ;{ }^{13} \mathrm{C} \times \mathrm{MR}\left(100 \mathrm{MHz}, \mathrm{CDCl}_{3}\right) \delta 161.5$ (d, $J=4.6 \mathrm{~Hz}), 137.9(\mathrm{~d}, J=4.6 \mathrm{~Hz}), 135.9\left(\mathrm{~d}, J_{\mathrm{P} \cdot \mathrm{C}}=94.0\right.$ $\mathrm{Hz}), 132.9(\mathrm{~d}, J=3.8 \mathrm{~Hz}), 131.0(\mathrm{~d}, J=12.1 \mathrm{~Hz}), 128.4(\mathrm{~d}, J$ $=15.2 \mathrm{~Hz}), 117.3(\mathrm{~d}, J=7.6 \mathrm{~Hz}), 114.9(\mathrm{~d}, J=3.0 \mathrm{~Hz}), 55.4$ (s, OCH $\mathrm{OH}_{3}$; ${ }^{31} \mathrm{P}$ NMR (162 MHz, CDCl $\left.1_{3}\right) \delta 94.1$ (s, 1P); IR (KBr, cm ${ }^{-1}$ ) 3061 (C-H, aromatic), 2947, $2841\left(-\mathrm{CH}_{3}\right), 1493$ $(\mathrm{C}=\mathrm{C}, \mathrm{Ar}), 1438(\mathrm{P}-\mathrm{C}, \mathrm{Ar}), 828(\mathrm{P}=\mathrm{S}) ; \mathrm{GCMS}: \mathrm{m} / \mathrm{z}, 314$ (M); Anal. Caled for $\mathrm{C}_{13} \mathrm{H}_{12} \mathrm{OPS}_{2} \mathrm{Cl}: \mathrm{C}, 49.60 ; \mathrm{H}, 3.84$; Found: C, 49.90; H, 3.88.

$S$-(4-Methylphenyl) phenyl phosphonochloridothioate. White solid; $\operatorname{mp} 87-88^{\circ} \mathrm{C}$; ${ }^{1} \mathrm{H}$ XMR $\left(400 \mathrm{MHz}, \mathrm{CDCl}_{3}\right) \delta$ $7.96(\mathrm{dd}, J=16.5,6.5 \mathrm{~Hz}, 2 \mathrm{H}), 7.57-7.53(\mathrm{~m}, 1 \mathrm{H}), 7.49-7.43$ $(\mathrm{m}, 2 \mathrm{H}), 7.28-7.24(\mathrm{~m}, 2 \mathrm{H}), 7.11(\mathrm{~d}, J=7.0 \mathrm{~Hz}, 2 \mathrm{H}) 2.33(\mathrm{~s}$, $\left.3 \mathrm{H}, \mathrm{CH}_{3}\right) ;{ }^{13} \mathrm{C} \times \mathrm{MR}\left(100 \mathrm{MHz}, \mathrm{CDCl}_{3}\right) \delta 140.9$ (d, $J=4.5$ $\mathrm{Hz}), 136.2\left(\mathrm{~d}, J=5.3 \mathrm{~Hz}\right.$ ), $136.0\left(\mathrm{~d}, J_{\mathrm{Pcc}}=95.5 \mathrm{~Hz}\right), 132.9$ (d, $J=3.8 \mathrm{~Hz}), 131.0(\mathrm{~d}, J=12.9 \mathrm{~Hz}), 130.1(\mathrm{~d}, J=3.8 \mathrm{~Hz})$, $128.4(\mathrm{~d}, J=15.2 \mathrm{~Hz}), 123.3(\mathrm{~d}, J=7.6 \mathrm{~Hz}), 21.4\left(\mathrm{~s}, \mathrm{CH}_{3}\right)$; ${ }^{31} \mathrm{P} \mathrm{NMR}\left(162 \mathrm{MHz}, \mathrm{CDCl}_{3}\right) \delta 93.6(\mathrm{~s}, \mathrm{PP}) ; \mathrm{IR}\left(\mathrm{KBr}, \mathrm{cm}^{-1}\right)$ 3056 (C-H, aromatic), $2917\left(-\mathrm{CH}_{3}\right), 1479(\mathrm{C}=\mathrm{C}, \mathrm{Ar}), 1439$ (P-C, Ar), $739(\mathrm{P}=\mathrm{S})$; GCMS: $\mathrm{m} / \mathrm{z}, 298\left(\mathrm{M}^{+}\right)$; Anal. Caled for $\mathrm{C}_{13} \mathrm{H}_{12} \mathrm{PS}_{2} \mathrm{Cl}$ : C, 52.26; H, 4.05; Found: $\mathrm{C}, 52.41 ; \mathrm{H}, 3.83$.

$S$-(3-Methylphenyl) phenyl phosphonochloridothioate. Colourless liquid; ${ }^{3} \mathrm{H} \times \mathrm{MR}\left(400 \mathrm{MHz}, \mathrm{CDCl}_{3}\right) \delta 7.96$ (dd, $J$ 
$=16.0,6.4 \mathrm{~Hz}, 2 \mathrm{H}), 7.59-7.55(\mathrm{~m}, 1 \mathrm{H}), 7.50-7.45(\mathrm{~m}, 2 \mathrm{H})$. 7.24-7.20 (m, 3H). 7.17 (s, 1H), 2.29 (s,3H, $\left.\mathrm{CH}_{3}\right) ;{ }^{13} \mathrm{C} \mathrm{NMR}$ $\left(100 \mathrm{MHz}, \mathrm{CDCl}_{3}\right) \delta 139.0(\mathrm{~d}, J=3.8 \mathrm{~Hz}), 136.7$ (d, $J=5.3$ $\mathrm{Hz}), 135.6\left(\mathrm{~d}, J_{\mathrm{P} . \mathrm{C}}=95.5 \mathrm{~Hz}\right), 133.1(\mathrm{~d}, J=4.6 \mathrm{~Hz}), 132.8$ (d, $J=3.0 \mathrm{~Hz}), 131.1$ (d, $J=3.8 \mathrm{~Hz}), 130.7(\mathrm{~d}, J=12.1 \mathrm{~Hz})$, $128.9(\mathrm{~d}, J=3.0 \mathrm{~Hz}), 128.2(\mathrm{~d}, J=15.1 \mathrm{~Hz}), 126.3(\mathrm{~d}, J=$ $7.6 \mathrm{~Hz}), 21.1\left(\mathrm{~s}, \mathrm{CH}_{3}\right) ;{ }^{31} \mathrm{P}$ XMR $\left(162 \mathrm{MHz}, \mathrm{CDCl}_{3}\right) \delta 93.4$ (s. 1P); IR (neat, $\left.\mathrm{cm}^{-1}\right) 3054(\mathrm{C}-\mathrm{H}$, aromatic), 2920, 2850 $\left(-\mathrm{CH}_{3}\right), 1475(\mathrm{C}=\mathrm{C}, \mathrm{Ar}), 1437$ (P-C, Ar), 780 (P=S); GCMS: $\mathrm{m} / \mathrm{Z}, 298\left(\mathrm{M}^{-}\right)$; Anal. Calcd for $\mathrm{C}_{13} \mathrm{H}_{12} \mathrm{PS}_{2} \mathrm{Cl}: \mathrm{C}, 52.26 ; \mathrm{H}$. 4.05; Found: C. $52.74 ; \mathrm{H}, 3.80$.

$S$-Phenyl phenyl phosphonochloridothioate. ${ }^{10}$ White solid; mp 86-87 ${ }^{\circ} \mathrm{C}$; ${ }^{1} \mathrm{H} \mathrm{NMR}\left(400 \mathrm{MHz}, \mathrm{CDCl}_{\text {; }}\right) \delta 7.97$ (dd. $J=16.8 .8 .0 \mathrm{~Hz}, 2 \mathrm{H}), 7.60-7.55(\mathrm{~m}, 1 \mathrm{H}), 7.50-7.40(\mathrm{~m}, 5 \mathrm{H})$, 7.35-7.31 (m, 2H); ${ }^{13} \mathrm{C}$ NMR (100 MHz, CDCl $) \delta 136.5$. $135.9\left(\mathrm{~d}, J_{\mathrm{P} . \mathrm{C}}=94.7 \mathrm{~Hz}\right), 133.1(\mathrm{~d}, J=3.8 \mathrm{~Hz}), 131.0(\mathrm{~d}, J=$ $12.9 \mathrm{~Hz}), 130.5(\mathrm{~d}, J=4.5 \mathrm{~Hz}), 129.3(\mathrm{~d} . J=3.8 \mathrm{~Hz}), 128.4$ $(\mathrm{d}, J=15.9 \mathrm{~Hz}), 127.0(\mathrm{~d}, J=15.9 \mathrm{~Hz}) ;{ }^{31} \mathrm{P} \times \mathrm{MR}(162$ $\left.\mathrm{MHz}, \mathrm{CDCl}_{\text {s }}\right) \delta 93.2$ (s, $1 \mathrm{P}$ ); $\mathbb{R}\left(\mathrm{KBr}, \mathrm{cm}^{-1}\right) 3640(\mathrm{C}-\mathrm{H}, \mathrm{Ar}$ ), $1434(\mathrm{C}=\mathrm{C}, \mathrm{Ar}), 1396(\mathrm{P}-\mathrm{C}, \mathrm{Ar}), 806(\mathrm{P}=\mathrm{S}) ; \mathrm{GCMS}: \mathrm{m} / \mathrm{z}$. $284\left(\mathrm{M}^{+}\right)$; Anal. for $\mathrm{C}_{12} \mathrm{H}_{11} \mathrm{PS}_{2} \mathrm{Cl}$ : C, $50.61 ; \mathrm{H}, 3.54$; Found: C. $50.93 ; \mathrm{H}, 3.58$.

$S$-(3-Methoxyphenyl) phenyl phosphonochloridothioate. Colourless liquid; ${ }^{1} \mathrm{H}$ NMR (400 MHz, $\left.\mathrm{CDCl}_{3}\right) \delta 7.97$ (dd. $J=16.8 .8 .1 \mathrm{~Hz}, 2 \mathrm{H}), 7.60-7.56(\mathrm{~m} .1 \mathrm{H}), 7.51-7.46(\mathrm{~m}$. $2 \mathrm{H}), 7.23(\mathrm{t}, J=8.2 \mathrm{~Hz}, 1 \mathrm{H}), 7.01-6.96(\mathrm{~m}, 2 \mathrm{H}), 6.92-6.91$ $(\mathrm{m}, 1 \mathrm{H}), 3.80\left(\mathrm{~s}, 3 \mathrm{H}, \mathrm{OCH}_{3}\right) ;{ }^{3} \mathrm{C} \mathrm{NMR}\left(100 \mathrm{MHz}, \mathrm{CDCl}_{3}\right) \delta$ $159.8(\mathrm{~d}, J=3.8 \mathrm{~Hz}), 136.0\left(\mathrm{~d}, J_{\mathrm{P} \cdot \mathrm{C}}=96.2 \mathrm{~Hz}\right), 133.1$ (d, $J=$ $3.1 \mathrm{~Hz}), 131.1$ (d. $J=12.9 \mathrm{~Hz}), 130.0($ d. $J=8.7 \mathrm{~Hz}), 128.5$ $(\mathrm{d}, J=19.0 \mathrm{~Hz}), 127.9(\mathrm{~d}, J=7.6 \mathrm{~Hz}), 120.9(\mathrm{~d}, J=4.5 \mathrm{~Hz})$, 119.6, $117.1(\mathrm{~d}, J=4.6 \mathrm{~Hz}), 55.6\left(\mathrm{~s}, \mathrm{OCH}_{3}\right)$; ${ }^{3} \mathrm{P}$ NMR (162 $\left.\mathrm{MHz}, \mathrm{CDCl}_{3}\right) \delta 92.9$ (s. 1P); IR (neat. $\mathrm{cm}^{-1}$ ) $3062(\mathrm{C}-\mathrm{H}$. aromatic), 2937, $2837\left(-\mathrm{CH}_{3}\right), 1479(\mathrm{C}=\mathrm{C}, \mathrm{Ar}), 1437$ (P-C, Ar), $856(\mathrm{P}=\mathrm{S})$; GCMS: m/z, $314\left(\mathrm{M}^{-}\right)$; Anal. Calcd for $\mathrm{C}_{13} \mathrm{H}_{12} \mathrm{OPS}_{2} \mathrm{Cl}: \mathrm{C}, 49.60 ; \mathrm{H}, 3.84$; Found: $\mathrm{C}, 49.76 ; \mathrm{H}, 3.90$.

Product analysis. S-(4-Methylphenyl) phenylphosphonochloridothioate was treated with excess 4-methoxyaniline for more than 15 half-lives at $55.0^{\circ} \mathrm{C}$ in acetonitrile. 4 methoxyaniline hydrochloride salt was separated as ether insoluble part by filtration. A reddish brown gummy product was isolated from ether soluble part by a work-up process with ether and water which was dried over anhydrous $\mathrm{MgSO}_{4}$ and followed by the evaporation of the solvent under reduced pressure after filtration. The physical constants are as follows.

[(4- $\left.\mathrm{CH}_{3}-\mathrm{C}_{6} \mathrm{H}_{4} \mathrm{~S}\right)\left(\mathrm{C}_{6} \mathrm{H}_{5}\right) \mathrm{P}(\mathrm{S})\left(\mathrm{NH}-\mathrm{C}_{6} \mathrm{H}_{4}-\mathbf{4}-\mathrm{OCH}_{3}\right]:$ Reddish brown gummy substance; ${ }^{1} \mathrm{H} \mathrm{NMR}\left(400 \mathrm{MHz}, \mathrm{CDCl}_{3}\right.$ ) $\delta 7.90(\mathrm{dd}, J=14.5 .7 .7 \mathrm{~Hz}, 2 \mathrm{H}), 7.53-7.51(\mathrm{~m}, 1 \mathrm{H}), 7.47-$ $7.44(\mathrm{~m}, 2 \mathrm{H}), 7.18(\mathrm{~d}, J=7.2 \mathrm{~Hz}, 2 \mathrm{H}), 7.08(\mathrm{~d}, J=7.2 \mathrm{~Hz}$, $2 \mathrm{H}), 6.97(\mathrm{~d}, J=8.8 \mathrm{~Hz}, 2 \mathrm{H}), 6.79(\mathrm{~d}, J=8.8 \mathrm{~Hz}, 2 \mathrm{H}), 4.92$ $(\mathrm{d}, J=6.8 \mathrm{~Hz}, \mathrm{~N}-\mathrm{H}, 1 \mathrm{H}), 3.76\left(\mathrm{~s}, 3 \mathrm{H}, \mathrm{OCH}_{3}\right), 2.33(\mathrm{~s}, 3 \mathrm{H}$, $\left.\mathrm{CH}_{3}\right) ;{ }^{13} \mathrm{C} \mathrm{NMR}\left(100 \mathrm{MHz}, \mathrm{CDCl}_{3}\right) \delta 155.4(\mathrm{~s}), 139.9(\mathrm{~d}, J=$ $3.0 \mathrm{~Hz}$ ), 136.2 (d. $J=3.8 \mathrm{~Hz}), 134.9$ (d. $J_{\mathrm{PCC}}=105.4 \mathrm{~Hz}$ ), 132.6 (d. $J=4.5 \mathrm{~Hz}), 132.2(\mathrm{~d}, J=3.0 \mathrm{~Hz}), 130.7$ (d, $J=$ $11.4 \mathrm{~Hz}), 129.8(\mathrm{~d}, J=2.3 \mathrm{~Hz}), 128.6(\mathrm{~d}, J=14.4 \mathrm{~Hz}), 124.0$ $(\mathrm{d}, J=6.1 \mathrm{~Hz}), 121.7(\mathrm{~d}, J=6.0 \mathrm{~Hz}), 114.3(\mathrm{~s}), 55.5\left(\mathrm{~s}, \mathrm{OCH}_{3}\right)$, $21.4\left(\mathrm{~s}, \mathrm{CH}_{3}\right) ;{ }^{31} \mathrm{P} \times \mathrm{MR}\left(162 \mathrm{MHz}, \mathrm{CDCl}_{3}\right) \delta 73.2(\mathrm{~s}, 1 \mathrm{P})$;
IR $\left(\mathrm{KBr}, \mathrm{cm}^{-1}\right) 3271(-\mathrm{NH}-), 3076,(\mathrm{C}-\mathrm{H}$, aromatic), 2928, $2861\left(-\mathrm{CH}_{3}\right), 1510(\mathrm{C}=\mathrm{C}, \mathrm{Ar}) 1438(\mathrm{P}-\mathrm{C}, \mathrm{Ar}), 809(\mathrm{P}=\mathrm{S})$; GCMS: $\mathrm{m} / \mathrm{z}, 385\left(\mathrm{M}^{+}\right)$; Anal. Calcd for $\mathrm{C}_{2(1} \mathrm{H}_{20} \mathrm{ONPS}_{2}: \mathrm{C}$, $62.31 ; \mathrm{H}, 5.23 ; \mathrm{N}, 3.63$. Found: $\mathrm{C}, 62.59 ; \mathrm{H}, 5.25 ; \mathrm{N}, 3.47$.

Kinetic measurements. The kinetic study was performed with a computer controlled conductivity bridge. All the reactions were carried out under pseudo-first-order conditions, using large excesses of nucleophiles: [Substrate] $=3 \times$ $10^{-3} \mathrm{M},[\mathrm{X}$-Aniline $]=0.5-0.9 \mathrm{M}$. At least five different aniline concentrations were employed and replicate values of $k_{\text {olss }}$

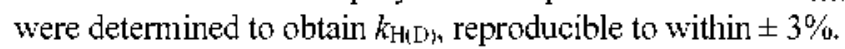

Acknowledgments. This work was supported by the Korea Research Foundation (KRF-2008-314-C00207).

\section{References}

1. Anilinolvis: (a) Guha, A. K.; Lee, H. W.; Lee, I. J. Chem. Soc, Perkin Trans. 2 1999, 765. (b) Lee, H. W.; Gulha, A. K.; Lee, I. Int. J. Chem. Kinet. 2002, 34, 632. (c) Hoque, M. E. L.; Dey, S.; Guha, A. K.; Kim, C. K.; Lee, B. S.; Lee, H. W. J. Org. Chem. 2007, 72, 5493. (d) Hoque, M. E. L.; Lee, H. W. Bmll. Konean Chem. Soc. 2007, 28, 936. (e) Dey, N. K.; Han, 1. S.; Lee, H. W. Bull. Korean Chem. Soc. 2007, 28, 2003. (f) Hoque, M. E. L.; Dey, N. K.: Kim, C. K.; Lee, B. S.; Lee, H. W. Org. Bionol. Chem. 2007, 5, 3944. (g) Dey, N. K.; Hoque, M. E. U.; Kim, C. K.; Lee, B. S.; Lee, H. W. J. Phws. Org. Chem. 2008, 21, 544. Pyridinolvsis: (h) Guha, A. K.; Lee, H. W; Lee, I. J. Org. Chem. 2000, 65, 12. (i) Lee, H. W; Guha, A. K.; Kim, C. K.; Lee, I. $J$ Org. Chem. 2002, 67, 2215. (j) Adhikary, K. K.; Lee, H. W.; Lee, I. Bull. Korean Chen. Soc. 2003, 24, 1135. (k) Hoque, M. E. L.; Dey, N. K.; Guha, A. K.; Kim, C. K.; Lee, B. S.; Lee, H. W. Bull. Korean Chem. Soc. 2007, 28, 1797. (1) Adhikary, K. K.; Lumbiny, B. J.; Kim, C. K.; Lee, H. W. Bull. Korean Chem. Soc. 2008, 29 , 851. (m) Lumbiny, B. J.; Adhikary, K. K.; Lee, B. S.; Lee, H. W. Bull. Korean Chem. Soc. 2008, 29, 1769. Theoretical: (n) Lee, I: Kim, C. K.; Li, H. G; Sohn, C. K.; Kim, C. K.; Lee, H. W.; Lee, B. S.J. Am. Chem. Soc. 2000, 122, 11162.

2. (a) Lee, I. Chem. Soc Rer: 1990, 19, 317. (b) Lee, I. Adr. Phrs. Org. Chem. 1992, 27, 57. (c) Lee, 1.; Lee, H. W. Collect. Csech. Chent. Commm. 1999, 64, 1529

3. Hansch, C.; Leo, A.; Taft, R. W. Chem. Rev. 1991, 91, 165.

4. Streitwieser, A. Ir.; Heathcock, C. H. Introduction to Organic Chemistri, 3rd ed.; Macmillan publishing Co.: New York, 1989; $\mathrm{p}$ 693.

5. (a) Lee, 1; Kol, H. J.; Lee, B. S.; Lee, H. W. J. Chem. Soc, Chem. Conmun 1990, 335. (b) Melander, L.; Saunders, Jr. W. H. Recction Rates of Isotopic Molecules; Wiley: New York, 1981. (c) Kaldor, S. B.; Saunders, Jr. W. H. J. Chem. Phrs. 1978, 68, 2509. (d) Swain, C. C.; Pegues, E. E. I. Am. Chen. Soc. 1958, 80, 812. (e) Kwart, H. Acc. Chem. Res. 1982, 15, 401. (f) Kwart, H.; Brechbid, M. W. Acheson, R. V.; Ward, D. C. J. An. Chem. Soc. 1982, 104, 4671.

6. Crumpler, T. B.; Yoh, J. H. Chemical Computations and Errors: John Wiley: New York, 1940; p 178.

7. Hehre, W. J.; Random, L.; Schleyer, P. V. R.; Pople, J. A. Ab Initio Molecular Orbital Theon: Wiley: New York, 1986; Chapter 4.

8. (a) Banes, J. A.: Williams, 1. A. J. Chem. Soc, Chem. Commun. 1993, 1286. (b) Poirier, R. A.; Wang, Y; Westaway, K. C. J. An. Chem. Soc. 1994, 116,2526 .

9. The obtained activation enthalpy and entropy values from the secondorder rate constants at $55.0,60.0$, and $65.0^{\circ} \mathrm{C}$ are as follows: $\Delta H^{F}$ $=4.5 \pm 0.6 \mathrm{kcal} / \mathrm{mol}$ and $\Delta S^{-5}=\$ 8=2$ e.u. for $\mathrm{X}=4-\mathrm{MeO}$ and $\mathrm{Y}=$ 4-Me, $\Delta H^{F}=2.5 \pm 0.1$ and $\Delta S^{x}=64 \pm 1$ for $\mathrm{X}=4-\mathrm{MeO}$ and $\mathrm{Y}=$ 3-MeO, $\Delta H^{*}=2.4=0.1$ and $\Delta S^{*}=69=1$ for $\mathrm{X}=\mathrm{H}$ and $\mathrm{Y}=4$ $\mathrm{Me}$, and $\Delta H^{F}=3.8=0.6$ and $\Delta S^{+}=65=2$ for $\mathrm{X}=\mathrm{H}$ and $\mathrm{Y}=\mathrm{H}$.

10. Grapov, A. F.; Lebedeva, N. V.; Mel'nikov, N. N. Zhimal Obshchei Khimii 1968, 38, 2658. 